\title{
Productive characteristics of meat quails reared in different environments
}

\section{Características produtivas de codornas de corte mantidas em diferentes ambientes}

\author{
Dihego Silva Bonfim $^{1 *}$; Jefferson Costa de Siqueira ${ }^{2}$; \\ Marcos Antonio Delmondes Bomfim²; Felipe Barbosa Ribeiro²; \\ Francisco Loiola de Oliveira ${ }^{3}$; Daphinne Cardoso Nagib Nascimento ${ }^{4}$; \\ Solange de Araujo Melo ${ }^{5}$
}

\begin{abstract}
The objective of this study was to evaluate the effects of ambient temperature and consumption on the performance, carcass yields and cuts, organs, and body temperatures of meat quails. The experiment was conducted at the Federal University of Maranhão, campus of Chapadinha-MA, during September to October 2013. From the 14th day of age, 450 meat quails, not sexed, with an average initial weight of $90.4 \pm 12.9 \mathrm{~g}$, were distributed in batteries and accommodated in either acclimatized or non-acclimatized rooms, until 42 days of age. The experimental design was completely randomized, with three treatments, and six replicates of 25 birds each. The treatments were $\mathrm{CE}$ (acclimatized environment at $26^{\circ} \mathrm{C}$ ); NE (natural environment), and CECC (acclimatized environment at $26^{\circ} \mathrm{C}$ with controlled feed, to keep the same consumption level as that of the birds in NE). The evaluated variables at 28 and 42 days of age were as follows: (1) the intake of feed, weight gain, feed conversion, body weight, and energy efficiency to weight gain, (2) the carcass weight, carcass yields (\%) for breast, thigh, drumstick, and wing, and (3) the relative weights (\%) of the digestive tract, heart, liver, gizzard, and intestine. In addition, we evaluated the cloacal and surface temperatures $\left({ }^{\circ} \mathrm{C}\right)$, and subsequently, calculated the average and surface body temperatures. The treatment means were compared using the Student-Newman-Keuls test, with 5\% level of significance. Compared with the acclimatized ambient environment, the natural environment more favored the performance of quails up to 28 days, but then affected it negatively from that age onward. Carcass yield, organs, and internal temperature of the quails maintained in the acclimatized and natural environments were not influenced.
\end{abstract}

Key words: Coturnix coturnix coturnix. Performance. Relative weights. Temperatures. Yields.

\section{Resumo}

Objetivou-se avaliar os efeitos da temperatura ambiente sobre o desempenho, rendimentos de carcaça e cortes, órgãos e temperaturas corporais de codornas de corte. O experimento foi conduzido na

\footnotetext{
${ }^{1}$ Mestre em Ciência Animal, Centro de Ciências Agrárias e Ambientais, Universidade Federal do Maranhão, CCAA/UFMA, Chapadinha, MA, Brasil. E-mail: dihegozootecnia@hotmail.com

2 Profs., Centro de Ciências Agrárias e Ambientais, Universidade Federal do Maranhão, CCAA/UFMA, Chapadinha, MA, Brasil. E-mail: jc.siqueira@ufma.br; mad.bomfim@ufma.br; felipe.barbosa@ufma.br

${ }^{3}$ Graduado em Zootecnia, UFMA, Chapadinha, MA, Brasil. E-mail: loiola93@gmail.com

${ }^{4}$ Doutorado em Ciência Animal, Universidade Federal do Piauí, UFPI, Bom Jesus, PI, Brasil. E-mail: daphinnec@yahoo.com.br

${ }^{5}$ Prof ${ }^{a}$., UEMA, Balsas, MA, Brasil. E-mail: sol-vet@hotmail.com

* Author for correspondence
} 
Universidade Federal do Maranhão, campus de Chapadinha-MA, no período de setembro a outubro de 2014. A partir do $14^{\circ}$ dia de idade, 450 codornas de corte, não sexadas, com o peso inicial médio de 90,4 $\pm 12,9 \mathrm{~g}$, foram distribuídas em baterias, acondicionadas em sala climatizada e não climatizada, até o $42^{\circ}$ dia. O delineamento experimental foi o inteiramente casualizado, com três tratamentos e seis repetições de 25 aves. Os tratamentos consistiram em: AC (Ambiente climatizado com temperatura de $26^{\circ} \mathrm{C}$ ); AN (Ambiente natural) e ACCC (Ambiente climatizado com temperatura de $26^{\circ} \mathrm{C}$ com alimentação controlada para manter o mesmo consumo das aves mantidas no AN). Foi avaliado o consumo de ração, ganho de peso, conversão alimentar, peso vivo, eficiência energética para ganho de peso; o peso de carcaça, rendimentos (\%) de carcaça, peito, coxa, sobrecoxa e asa; os pesos relativos (\%) do trato digestório, coração, fígado, moela e intestino aos 28 e aos 42 dias. Também foram avaliadas as temperaturas $\left({ }^{\circ} \mathrm{C}\right)$ cloacais e superficiais, e posteriormente, calculadas a superficial média e corporal média. As médias dos tratamentos foram comparadas pelo teste SNK considerando o nível de 5\% de significância. $\mathrm{O}$ ambiente natural melhorou o desempenho das codornas até os 28 dias, prejudicando a partir dessa idade em relação ao ambiente climatizado. Os rendimentos de carcaça, órgãos e a temperatura interna das codornas mantidas nos ambientes climatizado e natural, não foram influenciados.

Palavras-chave: Coturnix coturnix coturnix. Desempenho. Pesos relativos. Rendimentos. Temperaturas.

\section{Introduction}

High ambient temperature is one of the factors that have negative effects on feed intake, and consequently, on the productive characteristics of birds, resulting in economic losses to poultry farmers. The reduction of feed intake with increase in the ambient temperature is well-documented for broilers (EL-DEEP et al., 2014), laying hens (OLIVEIRA et al., 2014), turkeys (VELDKAMP et al., 2005), and laying quails (OZBEY; OZCELIK, 2004).

Studies of broilers maintained at high temperatures $\left(32{ }^{\circ} \mathrm{C}\right)$ have allowed us to conclude that approximately $60 \%$ of the decrease in performance is indirectly due to a reduction in consumption, the other $40 \%$ being the direct result of the effects of temperature (BONNET et al., 1997; GERAERT et al., 1996). In this context, part of the decrease in the birds' performance might be caused by the deficit of energy and nutrients, and the remaining is associated with the increase in energy spent for heat dissipation, which is necessary for the maintenance of homeothermy.

The breeding of meat quails (Coturnix coturnix coturnix) has great potential for expansion in Brazil, as it requires only a small area for development, low manpower, and low investment but ensures quick return of capital. In addition, there is a growing demand for this type of meat in the consumer market, mainly due to the meat's characteristics such as intense color, smoothness, and flavor (PASTORE et al., 2012). Moreover, Sousa et al. (2014) mention that compared with chickens, meat quails have higher thermal comfort temperatures and might be more tolerant to high ambient temperatures because of a greater surface/volume ratio, suggesting greater ability to dissipate the heat generated by their metabolism.

Therefore, the breeding of meat quails can be a very important socio-economic activity, representing an alternative for many farmers in the Northeast region of Brazil, where temperatures remain high during most parts of the year.

Considering that only a few studies have evaluated the effects of ambient temperature on feed intake and productive characteristics of meat quails, the objective of this study was to evaluate the productive characteristics of meat quails reared at different environments, from 14 to 42 days of age.

\section{Materials and Methods}

The experiment was carried out from 25th September to 23rd October 2014, at the Agricultural and Environmental Sciences Center of the Federal 
University of Maranhão, located in the municipality of Chapadinha $\left(03^{\circ} 44^{\prime} 30^{\prime \prime} \mathrm{S}\right.$ and $\left.43^{\circ} 21^{\prime} 33^{\prime \prime} \mathrm{W}\right)$, at an altitude of $105 \mathrm{~m}$, as per the software SPRING 4.3.3 ${ }^{\circledR}$ (INPE, 2010). According to Köppen's climate classification, the region's climate corresponds to the Aw type, considered as a tropical zone with dry winter (ALVARES et al., 2013).

During the pre-experimental period (1-13 days of age), the quails were kept in brick sheds and housed in metal cages with a wood-shavings floor. The cages were fitted with $60 \mathrm{~W}$ incandescent bulbs, for maintaining the ambient temperature between $32{ }^{\circ} \mathrm{C}$ and $35^{\circ} \mathrm{C}$.

On the 14th day of age, 450 meat quails (Coturnix coturnix coturnix), not sexed, with an average starting weight of $90.4 \pm 12.9 \mathrm{~g}$, were randomly distributed in batteries, containing cages of $0.72 \mathrm{~m}^{2}$ $(0.85 \mathrm{~m} \times 0.85 \mathrm{~m})$, packed in two brickwork rooms with an area of $38 \mathrm{~m}^{2}(5.0 \mathrm{~m} \times 7.7 \mathrm{~m})$ and side windows. One of the rooms had an air conditioner with a capacity of 24,000 BTU/HR (British Thermal Unit $=252.2$ cal) to climatize the room, whereas the other one had no air conditioning, to mimic the conditions of the natural environment.

A completely randomized experimental design was used, with three treatments and six replicates of 25 birds each, totaling 18 experimental units (cages). The treatments were CE (acclimatized environment with temperature of $26{ }^{\circ} \mathrm{C}$ ); $\mathrm{NE}$ (natural environment), and CECC (acclimatized environment with temperature of $26^{\circ} \mathrm{C}$, but with controlled feeding to maintain the same consumption level as the birds kept in NE). CECC was used to isolate the effect of different environments on the feed intake of the birds.

The average, maximum, minimum, and black globe temperatures, as well as the relative humidity inside the premises, were monitored and recorded on a daily basis throughout the experimental period in the different environments (7:00 AM, 1:00 PM, and 7:00 PM), by using thermohygrometers located in the geometric centers of the rooms. To characterize the different environments, the Index of Globe Temperature and Humidity (IGTU) was calculated, as proposed by Buffington et al. (1981): IGTU = Tgn +0.36 Tpo -330.08 , where Tgn $=$ Black Globe Temperature $(\mathrm{K})$ and $\mathrm{Tpo}=$ Dew Point Temperature (K).

Continuous light was used throughout the experimental period ( $24 \mathrm{~h}$ of artificial light), with the help of $40 \mathrm{~W}$ fluorescent lamps.

The birds were fed rations based on corn and soybean meal, formulated to meet the nutritional requirements of meat quail during the breeding (1-21 days) and raising (22-42 days) phases, as recommended in the tables for Japanese and European Quails (SILVA; COSTA, 2009) (Table 1).

The quails of all experimental groups had free access to water and feed, except those of the CECC group, which received controlled feed so that they would consume the same amount of feed as that by the quails reared in NE (quantity from the previous day). For this, the feed consumption of the birds reared in NE was recorded daily and the same amount was supplied to the birds of the CECC group, as proposed by Geraert et al. (1996).

Feed intake (FI; g), live weight on the $28^{\text {th }}$ and $42^{\text {th }}$ days (W28 and W42; g), weight gain (WG; g), feed conversion ( $\mathrm{FC} ; \mathrm{g} / \mathrm{g}$ ), and energy efficiency (EEWG; g/Mcal) were quantified for quails of ages 14-28 days and for the cumulative age period of 1442 days. FI was obtained by the difference between the feed supplied and the remaining quantity in each period, divided by the number of birds, and was corrected according to mortality, considering the date of death as per Sakomura and Rostagno (2007). LW and WG for each period were obtained by weighing the birds in each group at 28 and 42 days of age. FC was calculated as the ratio of FI and WG. EEWG was calculated as the ratio of WG (g) and the consumption of metabolizable energy (Mcal), the latter being calculated as the product of FI $(\mathrm{kg})$ and metabolizable energy of the feed (Mcal/kg). 
Table 1. Rations formulated to meet the nutritional requirements of quails in the breeding and raising stages ${ }^{1}$.

\begin{tabular}{|c|c|c|}
\hline Ingredients (\%) & Breeding (1-21 days) & Raising (22-42 days) \\
\hline Corn & 52.005 & 60.577 \\
\hline Soybean meal & 43.466 & 36.019 \\
\hline Soya oil & 0.000 & 0.920 \\
\hline Dicalcium phosphate & 1.185 & 0.952 \\
\hline Limestone & 1.009 & 0.826 \\
\hline Sodium chloride & 0.376 & 0.325 \\
\hline DL-methionine $(98 \%)$ & 0.344 & 0.161 \\
\hline L-threonine $(98 \%)$ & 0.193 & 0.010 \\
\hline L-Lysine $\mathrm{HCl}(78.5 \%)$ & 0.025 & 0.000 \\
\hline Vitamin compound $^{2}$ & 0.100 & 0.100 \\
\hline Mineral compound ${ }^{3}$ & 0.050 & 0.050 \\
\hline Choline chloride $(60 \%)$ & 0.060 & 0.060 \\
\hline Inert (washed sand) & 1.187 & 0.000 \\
\hline Total & 100.00 & 100.00 \\
\hline \multicolumn{3}{|c|}{ Calculated Nutritional Compounds } \\
\hline Metabolizable energy $(\mathrm{kcal} / \mathrm{kg})$ & 2.950 & 3.100 \\
\hline Crude protein $(\%)$ & 25.00 & 22.00 \\
\hline Calcium $(\%)$ & 0.850 & 0.700 \\
\hline Available phosphorus (\%) & 0.320 & 0.270 \\
\hline Sodium $(\%)$ & 0.170 & 0.150 \\
\hline Chlorine $(\%)$ & 0.269 & 0.239 \\
\hline Potassium $(\%)$ & 1.091 & 0.959 \\
\hline Methionine + Digestible cystine (\%) & 1.040 & 0.800 \\
\hline Digestible Methionine (\%) & 0.686 & 0.477 \\
\hline Digestible Lysine (\%) & 1.370 & 1.178 \\
\hline Digestible Threonine (\%) & 1.040 & 0.780 \\
\hline Digestible Valine (\%) & 1.143 & 1.017 \\
\hline Digestible Isoleucine (\%) & 1.048 & 0.914 \\
\hline Digestible Tryptophan (\%) & 0.243 & 0.210 \\
\hline Raw fiber $(\%)$ & 3.255 & 3.061 \\
\hline Neutral detergent fiber (\%) & 9.222 & 9.320 \\
\hline Acid detergent fiber (\%) & 3.803 & 3.641 \\
\hline
\end{tabular}

${ }^{1}$ Rations formulated based on composition data of the food and nutritional requirements of heavy quails presented in the Tables for Japanese and European Quails (SILVA; COSTA, 2009). ${ }^{2}$ Composition $/ \mathrm{kg}$ of product: vit. A = 12,000,000 U.I.; vit. D3 = 3,600,000 U.I.; vit. E = 3,500 U.I.; vit B1 $=2,500 \mathrm{mg}$; vit. $\mathrm{B} 2=8,000 \mathrm{mg}$; vit. $\mathrm{B} 6=5,000 \mathrm{mg}$; Pantothenic acid $=12,000 \mathrm{mg}$; Biotin $=$ $200 \mathrm{mg}$; vit. $\mathrm{K}=3,000 \mathrm{mg}$; Folic acid = 1,500 mg; Nicotinic acid = 40,000 mg; vit. $\mathrm{B} 12=20,000 \mathrm{mg}$; $\mathrm{Se}=150 \mathrm{mg}$; vehicle q.s. ${ }^{3}$ Composition/kg of product: $\mathrm{Mn}=160 \mathrm{~g} ; \mathrm{Fe}=100 \mathrm{~g} ; \mathrm{Zn}=100 \mathrm{~g} ; \mathrm{Cu}=20 \mathrm{~g} ; \mathrm{Co}=2 \mathrm{~g} ; \mathrm{I}=2 \mathrm{~g}$; vehicle q.s.

On the $28^{\text {th }}$ and $42^{\text {nd }}$ days, two quails weighing close to the average weight of each experimental unit $( \pm 5 \%)$ were sampled, totaling 36 birds for each age, which were identified and kept under fasting for $6 \mathrm{~h}$, to reduce the contents of the digestive tract.
After fasting, the quails were killed by cervical dislocation, plucked, and eviscerated to obtain the weight of the carcass and offal, following the procedures approved by the Committee of Ethics in Animal Experimentation of the Federal University 
of Maranhão (Case No. 23115.002714/2014-74). Next, the carcass was cut (chest, thigh, drumstick, and wing) and the internal organs were separated (heart, liver, gizzard, and intestine [small intestine + ceca + colon]); each part and organ were then individually weighed.

The carcass yield (\%) (CY) was determined as the ratio of the weight of the eviscerated carcass $(\mathrm{CW})$ and the weight after fasting. Breast (BY), thigh (TY), drumstick (DSY), and wing (WY) yields, relative weights of the digestive tract (RWDT) (pharynx + esophagus + crop + proventriculus + gizzard + pancreas + liver + intestine) and organs (heart [RWHRT], liver [RWLIV], gizzard [RWGIZ], and intestine [RWINT]) were determined with respect to the $\mathrm{CW}$.

To check the effect of the environment on the body temperatures of quails at 28 and 42 days of age, two birds were randomly sampled from each group, and cloacal (CT) and surface (head, HDT; breast, BT; back BCKT, wing, WT; and legs, LGT) temperatures were measured at the time of day (1 PM) that was considered the most critical, by using clinical digital (Omron MC 245) and infrared (Instrutemp ITTI 380) thermometers, respectively. Based on these data, the average surface temperature was calculated $(\mathrm{AST}=0.12 * \mathrm{WT}+0.03 * \mathrm{HDT}+$ $0.15 * \mathrm{LGT}+0.70 * \mathrm{BCKT})$, followed by the average body temperature $(\mathrm{ABT}=0.3 * \mathrm{AST}+0.7 * \mathrm{TC})$ (RICHARDS, 1971).

Initially, data for all the assessed variables were subjected to a normality test (Cramer-Von Mises) and a homoscedasticity test (Levene); the values were in agreement to all assumptions, except in the case of FI. The data for this variable did not comply with the assumption of homoscedasticity, as the CECC group received controlled feed with respect to the NE group, thus, showing no significant variation across replicates. As a result, the FI variance analysis was carried out considering the $\mathrm{CE}$ and NE groups.
The data for each variable were subjected to variance analysis according to the following statistical model: $\mathrm{Y}_{\mathrm{ij}}=\mu+\mathrm{A}_{\mathrm{i}}+\mathrm{e}_{\mathrm{ij}}$; with $\mathrm{i}=1,2,3$ and $\mathrm{j}=1,2,3,4,5,6 \ldots$,

where $\mathrm{Y}_{\mathrm{ij}}=\mathrm{FI}, \mathrm{LW}, \mathrm{WG}, \mathrm{FC}, \mathrm{EEWG}, \mathrm{CW}, \mathrm{CY}$, BY, TY, DSY, WY, RWDT, RWHRT, RWLIV, RWGIZ, RWINT, CLT, HDT, BT, BCKT, WT, LGT, AST, or ABT of the birds kept in the $\mathrm{i}^{\text {th }}$ experimental group; $\mu=$ effect of the general average; $A_{i}=$ effect of the $\mathrm{i}^{\text {th }}$ experimental group; and $\mathrm{e}_{\mathrm{ij}}=$ experimental error associated to $\mathrm{j}^{\text {th }}$ replicate.

Subsequently, the averages of experimental groups for each variable for the two periods (14-28 and 14-42 days of age) were compared using the Student-Newman-Keuls test (SNK), considering a significance level of up to $5 \%$ probability. Statistical analyses were performed using the GLM procedure of the SAS Software 9.0 (2002).

\section{Results and Discussion}

During the trial period, the average, maximum, minimum, and black globe temperatures $\left({ }^{\circ} \mathrm{C}\right)$ recorded within the acclimatized environment were $26.1 \pm 0.62 ; 27.2 \pm 0.64 ; 24.8 \pm 0.80$, and $27.4 \pm 0.64$ ${ }^{\circ} \mathrm{C}$, respectively, with an average relative humidity of $69.5 \pm 9.25 \%$. In the non-acclimatized environment, these temperatures were $32.2 \pm 0.32 ; 34.5 \pm 0.61$; $29.9 \pm 0.54$, and $33.7 \pm 0.33{ }^{\circ} \mathrm{C}$, respectively, with a relative humidity of $56.8 \pm 2.26 \%$. The average temperature and relative humidity were $25.8 \pm 1.20$ ${ }^{\circ} \mathrm{C}$ and $67.5 \pm 3.89 \%$ at $7 \mathrm{Am}, 25.9 \pm 0.98{ }^{\circ} \mathrm{C}$ and $67.3 \pm 5.23 \%$ at $1 \mathrm{PM}$, and $25.8 \pm 1.15^{\circ} \mathrm{C}$ and 66.4 $\pm 6.17 \%$ at $7 \mathrm{PM}$, respectively, in the acclimatized environment, and $31.9 \pm 1.93{ }^{\circ} \mathrm{C}$ and $52.6 \pm 3.01 \%$ at $7 \mathrm{AM}, 32.8 \pm 1.98{ }^{\circ} \mathrm{C}$ and $67.3 \pm 5.40 \%$ at 1 $\mathrm{PM}$, and $32.2 \pm 1.90{ }^{\circ} \mathrm{C}$ and $52.4 \pm 3.02 \%$ at $7 \mathrm{PM}$, respectively, in the natural environment.

To characterize the thermal environment by using a single value that represents the impact of the variables affecting the thermal balance of the animal, 
Buffington et al. (1981) proposed the Black Globe and Humidity Index (BGHI), which has been used widely, as it incorporates, among other variables, the dry bulb temperature, black globe temperature, and relative humidity. Thus, the BGHI values throughout the experimental period were calculated, and the average values were found to be $75.8 \pm 1.36$ and $83.0 \pm 0.46$ in environments with and without air conditioning, respectively. The BGHI was $75.4 \pm$ 1.08 at $7 \mathrm{AM}, 75.3 \pm 1.45$ at $1 \mathrm{PM}$, and $75.2 \pm 1.66$ at $7 \mathrm{PM}$ in the climatized environment, and $82.3 \pm 1.30$ at $7 \mathrm{AM}, 83.4 \pm 0.91$ at $1 \mathrm{PM}$, and $82.6 \pm 1.33$ at $7 \mathrm{PM}$ in the natural environment.

Recently, Sousa et al. (2014) studied the effects of different thermal environments on the meat quails' performance from ages 22-35 days, in order to determine the thermal comfort ranges, expressed in terms of temperature $\left({ }^{\circ} \mathrm{C}\right)$ and BGHI. The authors concluded that temperatures between 25.6 and $26.7^{\circ} \mathrm{C}$, corresponding to BGHI values between 75.3 and 75.8 , characterize thermal comfort, whereas temperatures between 30.4 and $33.2{ }^{\circ} \mathrm{C}$, corresponding to $\mathrm{BGHI}$ values between 79.7 and 82.2, are characteristic of a moderate/ severe heat condition. Based on the results of Sousa et al. (2014), the average temperatures of 26.1 and $32.2{ }^{\circ} \mathrm{C}$ observed in this study, corresponding to BGHI of 75.8 and 83.0, would characterize the environment as comfortable and moderately/ severely hot, respectively.

FI (g), WG (g), FC (g/g), W28d (g), W42d (g), and EEWG (g/Mcal) of the quails were influenced by the environment $(\mathrm{P}<0.05)$, independent of the evaluation period (14-28 and 14-42 days) (Table 2).

Table 2. Feed intake (FI), weight gain (WG), feed conversion (FC), body weight (W28d, W42d), and energy efficiency for weight gain (EEWG) of meat quails kept in different environments for different evaluation periods (14-28 and 1442 days).

\begin{tabular}{|c|c|c|c|c|c|}
\hline \multirow{2}{*}{ Variable } & \multicolumn{3}{|c|}{ Treatments } & \multirow{2}{*}{$\mathrm{VC}^{1}$} & \multirow{2}{*}{$\mathrm{P}>\mathrm{F}^{2}$} \\
\hline & $\mathrm{CE}\left(26^{\circ} \mathrm{C}\right)$ & $\operatorname{NE}\left(32^{\circ} \mathrm{C}\right)$ & $\operatorname{CECC}\left(26^{\circ} \mathrm{C}\right)$ & & \\
\hline \multicolumn{6}{|l|}{ 14-28 days } \\
\hline $\mathrm{FI}^{3}(\mathrm{~g})$ & $346.37^{\mathrm{a}}$ & $330.50^{b}$ & 331.40 & 2.31 & 0.0056 \\
\hline WG (g) & $126.71^{\mathrm{a}}$ & $120.99^{b}$ & $106.96^{\mathrm{c}}$ & 2.37 & $<0.0001$ \\
\hline $\mathrm{FC}(\mathrm{g} / \mathrm{g})$ & $2.73^{\mathrm{b}}$ & $2.73^{b}$ & $3.09^{\mathrm{a}}$ & 2.42 & $<0.0001$ \\
\hline W28d (g) & $215.33^{\mathrm{a}}$ & $209.78^{b}$ & $195.25^{\mathrm{c}}$ & 1.46 & $<0.0001$ \\
\hline EEWG (g/Mcal) & $124.0^{\mathrm{a}}$ & $124.2^{\mathrm{a}}$ & $109.4^{\mathrm{b}}$ & 2.41 & $<0.0001$ \\
\hline \multicolumn{6}{|l|}{ 14-42 days } \\
\hline $\mathrm{FI}^{3}(\mathrm{~g})$ & $802.06^{\mathrm{a}}$ & $761.10^{\mathrm{b}}$ & 761.56 & 2.13 & 0.0017 \\
\hline WG (g) & $201.39^{a}$ & $184.89^{b}$ & $181.70^{\mathrm{b}}$ & 2.99 & $<0.0001$ \\
\hline $\mathrm{FC}(\mathrm{g} / \mathrm{g})$ & $3.99^{\mathrm{b}}$ & $4.12^{\mathrm{ab}}$ & $4.19^{\mathrm{a}}$ & 2.82 & 0.0220 \\
\hline W42d (g) & $290.02^{\mathrm{a}}$ & $273.68^{\mathrm{b}}$ & $270.18^{\mathrm{b}}$ & 2.00 & $<0.0001$ \\
\hline EEWG (g/Mcal) & $81.05^{\mathrm{a}}$ & $78.37^{\mathrm{ab}}$ & $76.97^{\mathrm{b}}$ & 2.94 & 0.0243 \\
\hline
\end{tabular}

Averages followed by the same letters in the same line do not differ by the SNK test $(\mathrm{P}>0.05)$.

${ }^{1}$ Variation Coefficient (\%).

${ }^{2}$ Significance of the "F" test of the variance analysis.

${ }^{3}$ For the variable FI, the variance analysis was performed with the $\mathrm{CE}$ and $\mathrm{NE}$ treatments.

In the initial period (14-28 days), it was in a decrease $(\mathrm{P}<0.05)$ of $4.51 \%$ in the WG and observed that the NE birds had lower FI $(\mathrm{P}<2.58 \%$ in W28d. As the reduction in WG was 0.05 ) by $4.58 \%$ when than those in $\mathrm{CE}$, resulting proportional to the reduction in FI, the FC and 
EEWG were similar $(\mathrm{P}>0.05)$ between these groups.

Considering the $26{ }^{\circ} \mathrm{C}$ ambient temperature, it was observed that quails in the CECC group showed a $4.32 \%$ lower FI than those of the CE group, resulting in a deterioration $(\mathrm{P}<0.05)$ of $15.59 \%$ in $\mathrm{WG}, 13.18 \%$ in $\mathrm{FC}, 9.32 \%$ in $\mathrm{W} 28 \mathrm{~d}$, and $11.77 \%$ in EEWG. As the deterioration observed in the performance variables of the CECC birds was greater than the reduction of the FI, it is possible that the ambient temperature of $26^{\circ} \mathrm{C}$ had a negative effect on the performance variables evaluated during 14-28 days of age.

Assuming that temperatures between 25.6 and $26.7{ }^{\circ} \mathrm{C}$ are characteristic of thermal comfort and temperatures between 30.4 and $33.2{ }^{\circ} \mathrm{C}$ represent moderate/severe heat (SOUSA et al., 2014), it was expected that quails of the CECC group would exhibit higher performance than those of the NE group, as has been noted in broilers (BONNET et al., 1997; GERAERT et al., 1996); however, the situation was precisely the opposite.

Quails from the CECC group consumed the same amount of feed as those in the NE group, however, there was a deterioration of $(\mathrm{P}<0.05)$ $11.60 \%$ in the WG, $13.18 \%$ in FC, $6.92 \%$ in $\mathrm{W} 28 \mathrm{~d}$, and $11.91 \%$ in EEWG, which confirms the fact that the temperature of $26{ }^{\circ} \mathrm{C}$ detracted the performance of quails till 28 days of age.

The lower performance of the CECC group compared with the NE group is probably associated with the increased metabolic activity, in order to increase heat production for maintaining thermal homeostasis, causing an increase in the net energy requirements for maintenance, and consequently, reducing the net energy available for gain (JORDÃO FILHO et al., 2011); this is supported by the observed worsening of EEWG. These results suggest that the range of thermal comfort for meat quails for 14-28 days of age is above $26{ }^{\circ} \mathrm{C}$, which differs from the recommendations of Sousa et al. (2014) $\left(25.6-26.7^{\circ} \mathrm{C}\right)$.
During the later accumulated period (14-42 days $)$, there was a decrease $(\mathrm{P}<0.05)$ of $5.11 \%$ in the FI of quails kept in NE, when compared with those of the CE group, which resulted in a reduction $(\mathrm{P}<0.05)$ of $8.19 \%$ in $\mathrm{WG}$ and $5.63 \%$ in $\mathrm{W} 42 \mathrm{~d}$, with no effect $(\mathrm{P}>0.05)$ on $\mathrm{FC}$ and EEWG.

At the ambient temperature of $26{ }^{\circ} \mathrm{C}$, it was observed that quails in the CECC group showed a $5.04 \%$ lower FI $(\mathrm{P}<0,05)$ than those of the $\mathrm{CE}$ group, resulting in a deterioration of $9.77 \%$ in $\mathrm{WG}$, $5.01 \%$ in $\mathrm{FC}, 6.84 \%$ in W42d, and 5.03\% in EEWG.

The reduction in WG due to FI was lower in the accumulated period (9.77\%) (14-42 days) than in the initial period (15.59\%) (14-28 days), which suggests that after 28 days, the ambient temperature of $26^{\circ} \mathrm{C}$ improved the performance of quails with respect to the $32{ }^{\circ} \mathrm{C}$ environment. The comparison between the CECC and NE groups reinforces this notion, as the quails from the CECC group showed similar FI, WG, FC, W42d, and EEWG (P > 0.05) to those in the NE group, during the accumulated period.

The evaluations in this study were conducted on the same birds, sequentially at 28 and 42 days of age, and therefore, comparisons involving the final period (28-42 days) are questionable from a statistical point of view, because of the residual effect of the initial phase (14-28 days). On the other hand, the results can help clarify the fact that quails of the CECC group showed a higher WG than did those of the NE group after 28 days, as 28-day-old quails of the CECC group showed a lower W28d $(195.25 \mathrm{~g})(\mathrm{P}<0.05)$ than did those of the NE group (209.78 g); however, after 42 days, the W42d was similar $(\mathrm{P}>0.05)$ between these groups $(270.18$ and $273.68 \mathrm{~g}$, respectively). These results confirm that the $26^{\circ} \mathrm{C}$ environment was more suitable than the $32{ }^{\circ} \mathrm{C}$ environment for quails from 28 to 42 days of age.

Studies on broilers kept at thermoneutral (22 $\left.{ }^{\circ} \mathrm{C}\right)$ and stressful $\left(32{ }^{\circ} \mathrm{C}\right)$ environment showed that approximately $60 \%$ of the reduction in performance 
is indirectly due to the reduction of consumption, while the remaining $40 \%$ is related to the direct effects of high temperature (BONNET et al., 1997; GERAERT et al., 1996). In this study, the division of the direct and indirect effects of ambient temperature for meat quails became impossible because the temperature of $26{ }^{\circ} \mathrm{C}$, recommended as thermally comfortable (SOUSA et al., 2014), lowered the birds' performance in the CECC group compared with the NE group, until 28 days of age, and favored the performance from that age onward.

The quails' $\mathrm{CW}(\mathrm{g})$ was affected $(\mathrm{P}<0.05)$ by the environment at 28 and 42 days of age, however, CY (\%), PR (\%), TY (\%), DSY (\%), and WY (\%) were similar $(\mathrm{P}>0.05)$ among the experimental groups at both age groups (Table 3 ).

Table 3. Carcass weight (CW), and carcass (CY), breast (BY), thigh (TY), drumstick (DSY), and wing (WY) yields of meat quails in different environments/feed intake at 28 and 42 days of age.

\begin{tabular}{|c|c|c|c|c|c|}
\hline \multirow{2}{*}{ Variable } & \multicolumn{3}{|c|}{ Treatments } & \multirow{2}{*}{$\mathrm{VC}^{1}$} & \multirow{2}{*}{$\mathrm{P}>\mathrm{F}^{2}$} \\
\hline & $\mathrm{CE}\left(26^{\circ} \mathrm{C}\right)$ & $\operatorname{NE}\left(32^{\circ} \mathrm{C}\right)$ & $\mathrm{CECC}\left(26^{\circ} \mathrm{C}\right)$ & & \\
\hline \multicolumn{6}{|l|}{28 Days } \\
\hline BW (g) & $172.96^{\mathrm{a}}$ & $164.11^{\mathrm{b}}$ & $159.50^{\mathrm{b}}$ & 3.57 & 0.0042 \\
\hline CY $(\%)$ & $80.33^{\mathrm{a}}$ & $78.21^{\mathrm{a}}$ & $80.95^{\mathrm{a}}$ & 3.62 & 0.2612 \\
\hline BY $(\%)$ & $33.31^{\mathrm{a}}$ & $32.75^{\mathrm{a}}$ & $33.95^{\mathrm{a}}$ & 2.49 & 0.0891 \\
\hline TY (\%) & $8.75^{\mathrm{a}}$ & $8.95^{\mathrm{a}}$ & $8.67^{\mathrm{a}}$ & 3.19 & 0.2592 \\
\hline DSY (\%) & $12.11^{\mathrm{a}}$ & $12.12^{\mathrm{a}}$ & $12.09^{\mathrm{a}}$ & 3.56 & 0.9942 \\
\hline WY (\%) & $8.16^{\mathrm{a}}$ & $8.48^{\mathrm{a}}$ & $8.37^{\mathrm{a}}$ & 4.41 & 0.3406 \\
\hline \multicolumn{6}{|l|}{42 days } \\
\hline BW (g) & $227.25^{\mathrm{a}}$ & $217.31^{b}$ & $216.51^{b}$ & 2.92 & 0.0225 \\
\hline CY $(\%)$ & $78.38^{\mathrm{a}}$ & $79.45^{\mathrm{a}}$ & $80.13^{a}$ & 3.16 & 0.4936 \\
\hline BY (\%) & $32.41^{\mathrm{a}}$ & $33.56^{\mathrm{a}}$ & $32.29^{\mathrm{a}}$ & 5.32 & 0.4434 \\
\hline TY (\%) & $8.02^{\mathrm{a}}$ & $7.95^{\mathrm{a}}$ & $8.32^{\mathrm{a}}$ & 5.16 & 0.2882 \\
\hline DSY $(\%)$ & $12.62^{\mathrm{a}}$ & $12.28^{\mathrm{a}}$ & $12.41^{\mathrm{a}}$ & 5.05 & 0.6495 \\
\hline WY (\%) & $7.23^{\mathrm{a}}$ & $7.40^{\mathrm{a}}$ & $7.32^{\mathrm{a}}$ & 4.44 & 0.7105 \\
\hline
\end{tabular}

Averages followed by the same letters in the same line do not differ by the SNK test $(\mathrm{P}>0.05)$.

${ }^{1}$ Variation Coefficient (\%).

${ }^{2}$ Significance of the "F" test of the variance analysis.

At 28 days of age, a decrease of $5.12 \%(\mathrm{P}<0.05)$ in the $\mathrm{CW}$ of NE quails was observed, along with a decrease of $7.78 \%$ in those from the CECC group, when compared with the $\mathrm{CE}$ quails. Although the $\mathrm{CW}$ of quails from the CE group (172.96 g) was higher $(\mathrm{P}<0.05)$, compared with the NE $(164.11 \mathrm{~g})$ and CECC (159.50 g) groups, it was observed that the $C Y$ was similar $(P>0.05)$ among the groups.

Similarly, at 42 days, the quails from the NE and CECC groups showed a decrease of $4.37 \%$ and $4.73 \%$, respectively, in $\mathrm{CW}(\mathrm{P}<0.05)$, when compared with those of the CE group, without any effect $(\mathrm{P}>0.05)$ on the $\mathrm{CY}$.

Studies with broilers demonstrated that high temperatures $\left(32{ }^{\circ} \mathrm{C}\right)$ induce a reduction in the size of the most metabolically active organs, in order to reduce the production of body heat, which results in increased carcass ratio:weight after fasting, and consequently, the increase of the carcass yield (OBA et al., 2012; ROSA et al., 2007); however, these changes were not evident in meat quails at 28 or 42 days of age. 
Evaluating the effect of environment on carcass characteristics of broilers at 42 days of age, Rosa et al. (2007) observed that an environment at $32{ }^{\circ} \mathrm{C}$ resulted in an increase in carcass $(2.58 \%)$ and thigh + drumstick (2.61\%) yield, along with lower breast yield $(11.19 \%)$, when compared with the group that was kept at $23{ }^{\circ} \mathrm{C}$. Oba et al. (2012) also observed an increase in the thigh + drumstick yield (34.65\%) and reduced breast yield (31.98\%) in 47-day old broilers kept at $32{ }^{\circ} \mathrm{C}$, compared with those kept at $22{ }^{\circ} \mathrm{C}$.

These results might be related to the fact that the broilers' breast muscle show a glycolytic metabolism (white fibers), whereas the muscles in the legs are characterized by oxidative metabolism (red fibers). Thus, due to broilers' panting during heat stress, higher breast muscle activity occurs, consuming part of the glycogen reserves and damaging muscle development. On the other hand, the yield of thigh + drumstick results from the formation of large amount of red fibers, and might show a considerable reserve of fat, which is used as an energy source (OBA et al., 2012).

Choi et al. (2014) reported that the breast muscle of flying birds, including quails, has a higher proportion of oxidative fibers (Type IIA) compared with the glycolytic type (Type IIB), while in broilers, this muscle predominantly includes glycolytic fibers (Type IIB). The authors explained the lower proportion of white fibers (glycolytic) in the breast of quails to the greater frequency of flight exercise, requiring high energy expenditure by glycolytic pathways, resulting in a greater proportion of red fibers (oxidative), compared with broilers.

Yunianto et al. (1997) associated the changes in muscle protein "turnover" of broilers kept at high temperatures to changes in the functions of the endocrine system, especially the rise of plasma corticosterone concentration. According to the results of Silva et al. (2005) in studies on mammals, the catabolic effects of steroid hormones (corticosterone and cortisol) are more intense on the glycolytic fibers than on the oxidative ones.

Considering that quails have a higher surfaceto-body volume ratio when compared with broilers, and consequently have a higher dissipation capacity of metabolic heat by sensitive media, it is possible that quails are less susceptible to changes in the endocrine system, allowing the plasma levels of corticosterone without major unbalances, even when kept at temperatures that are considered high for broilers.

Moreover, considering that the catabolic effects of steroid hormones are more intense on glycolytic fibers than on oxidative ones (SILVA et al., 2005), and given that quails have a higher proportion of oxidative fibers than broilers (CHOI et al., 2014), the absence of temperature effects on carcass and meat yield observed in this study might be justified.

At 28 days, no effects $(\mathrm{P}>0.05)$ of the environment were observed on the RWDT (\%), RWLIV (\%), RWGIZ (\%), and RWINT (\%) of quails, but there was an effect on their $(\mathrm{P}<0.05)$ RWHRT (\%). At 42 days, similar results were observed ( $\mathrm{P}>0.05)$ for RWDT, RWHRT, RWLIV, and RWINT, with the exception of RWGIZ, where the effect $(\mathrm{P}<0.05)$ of the environment/feed intake was evident (Table 4).

There was no direct effect of the environment observed on the RWHRT in 28-day old quails, since the NE group did not differ $(\mathrm{P}>0.05)$ from the CECC group, however, it was found $(\mathrm{P}<0.05)$ that the value of this variable was lower in birds of the $\mathrm{NE}$ and CECC groups when compared with those of the CE group. This superiority of CE quails in terms of RWHRT can be explained by the indirect effect of feed intake (FI), since the birds in this group had higher FI (346.37 g) than those of the NE (330.50 g) and CECC (331.40 g) groups. Generally, the higher FI might be related to an increased cardiac activity, to meet the demand for oxygen (WIDEMAN; TACKETT, 2000), mainly in birds with a higher body weight (OLIVEIRA NETO et al., 2005), as noted in quails of the CE group, in this study. 
Table 4. Relative weights of the digestive tract (RWDT), heart (RWHRT), liver (RWLIV), gizzard (RWGIZ), and intestine (RWINT) of quails in different environments/feed intake at 28 and 42 days of age.

\begin{tabular}{|c|c|c|c|c|c|}
\hline \multirow{2}{*}{ Variable } & \multicolumn{3}{|c|}{ Treatments } & \multirow{2}{*}{$\mathrm{VC}^{1}$} & \multirow{2}{*}{$\mathrm{P}>\mathrm{F}^{2}$} \\
\hline & $\mathrm{CE}\left(26^{\circ} \mathrm{C}\right)$ & $\operatorname{NE}\left(32^{\circ} \mathrm{C}\right)$ & $\operatorname{CECC}\left(26^{\circ} \mathrm{C}\right)$ & & \\
\hline \multicolumn{6}{|l|}{28 days } \\
\hline RWDT (\%) & $9.83^{\mathrm{a}}$ & $9.40^{\mathrm{a}}$ & $9.49^{a}$ & 5.53 & 0.4617 \\
\hline RWHRT (\%) & $1.09^{\mathrm{a}}$ & $0.97^{\mathrm{b}}$ & $0.95^{\mathrm{b}}$ & 4.66 & 0.0011 \\
\hline RWLIV (\%) & $3.10^{\mathrm{a}}$ & $3.14^{\mathrm{a}}$ & $2.92^{\mathrm{a}}$ & 7.31 & 0.2503 \\
\hline RWGIZ (\%) & $2.88^{\mathrm{a}}$ & $2.76^{\mathrm{a}}$ & $2.93^{\mathrm{a}}$ & 10.81 & 0.6402 \\
\hline RWINT (\%) & $2.92^{\mathrm{a}}$ & $2.80^{\mathrm{a}}$ & $2.99^{\mathrm{a}}$ & 10.82 & 0.6193 \\
\hline \multicolumn{6}{|l|}{42 days } \\
\hline RWDT (\%) & $8.94^{\mathrm{a}}$ & $8.00^{\mathrm{a}}$ & $9.14^{\mathrm{a}}$ & 11.27 & 0.1350 \\
\hline RWHRT (\%) & $1.02^{\mathrm{a}}$ & $0.96^{\mathrm{a}}$ & $1.05^{\mathrm{a}}$ & 8.70 & 0.2752 \\
\hline RWLIV (\%) & $3.13^{\mathrm{a}}$ & $2.53^{\mathrm{a}}$ & $2.90^{\mathrm{a}}$ & 14.00 & 0.0730 \\
\hline RWGIZ (\%) & $2.40^{\mathrm{a}}$ & $1.99^{\mathrm{b}}$ & $2.49^{\mathrm{a}}$ & 6.34 & 0.0002 \\
\hline RWINT (\%) & $3.16^{\mathrm{a}}$ & $2.97^{\mathrm{a}}$ & $2.80^{\mathrm{a}}$ & 14.49 & 0.3733 \\
\hline
\end{tabular}

Averages followed by the same letters in the same line do not differ by the SNK test $(\mathrm{P}>0.05)$.

${ }^{1}$ Variation Coefficient (\%).

${ }^{2}$ Significance of the "F" test of the variance analysis.

At 42 days of age, there was a decrease $(\mathrm{P}<$ $0.05)$ in the RWGIZ (\%) of NE quails compared with those from the CE and CECC groups, with no additional evidence to justify such a result.

Based on the results observed in broilers, it was expected that the quails kept at $32{ }^{\circ} \mathrm{C}$ would present a lower relative weight of the lower organs than those kept at $26^{\circ} \mathrm{C}$. However, this was not the case, which suggested that for physiological adaptation, there was no need to reduce the relative weight of these organs; the results were different from those obtained with broilers (ROSA et al., 2007; OLIVEIRA NETO et al., 2000).

Rosa et al. (2007) observed a decrease in the relative weights of the heart and liver in broiler chickens (42 days of age) kept under heat stress $\left(32{ }^{\circ} \mathrm{C}\right)$, compared with those kept at thermoneutral conditions $\left(23{ }^{\circ} \mathrm{C}\right)$. These authors linked the reduction in maintenance requirements to the decrease in mass of the internal organs and the lower metabolic activity of these organs in the birds kept at $32{ }^{\circ} \mathrm{C}$.
Oliveira Neto et al. (2000) also found a reduction of the relative weights of heart, liver, gizzard, and intestine in broilers (22-42 days of age) kept at 32 ${ }^{\circ} \mathrm{C}$, compared with those kept at $23{ }^{\circ} \mathrm{C}$. According to the authors, the high ambient temperatures can cause various adaptive physiological changes resulting in modification of the size of the organs.

The metabolic heat production rate is reduced when birds are exposed to high temperatures (GERAERT et al., 1996), increasing the plasma concentration of corticosterone and reducing the serum levels of triiodothyronine hormones (T3) and thyroxine (T4) (SAHIN et al., 2002), thus, changing the relative weight of the digestive tract and organs. Based on this, the physiological and hormonal changes in the quails (at 42 days of age) kept at $32{ }^{\circ} \mathrm{C}$ might not reach a high enough value to change the relative weights (RWDT (\%), RWHRT (\%), RWLIV (\%), and RWINT (\%)), confirming a greater resistance of these birds in hot environments, compared with broilers, as a consequence of the greater efficiency of dissipation of metabolic heat to the environment. 
At 28 and 42 days of age, it was observed that the CLT $\left({ }^{\circ} \mathrm{C}\right)$ of the quails was not influenced $(\mathrm{P}>0.05)$ by the environment. The $\mathrm{WT}\left({ }^{\circ} \mathrm{C}\right)$ at 28 days was also not influenced $(\mathrm{P}>0.05)$ by the environment (Table 5).

Table 5. Temperatures of the $\left({ }^{\circ} \mathrm{C}\right)$ cloaca (CLT), head (HT), breast (BT), back (BCKT), wing (WT), leg (LGT), and average surface (AST) and average body (ABT) temperature of quails (28- and 42-day old) in different environments.

\begin{tabular}{|c|c|c|c|c|c|}
\hline \multirow{2}{*}{ Variable } & \multicolumn{3}{|c|}{ Treatments } & \multirow{2}{*}{$\mathrm{VC}^{1}$} & \multirow{2}{*}{$\mathrm{P}>\mathrm{F}^{2}$} \\
\hline & $\mathrm{CE}\left(26^{\circ} \mathrm{C}\right)$ & $\operatorname{NE}\left(32^{\circ} \mathrm{C}\right)$ & $\operatorname{CECC}\left(26^{\circ} \mathrm{C}\right)$ & & \\
\hline \multicolumn{6}{|l|}{28 days } \\
\hline CLT & $40.46^{\mathrm{a}}$ & $40.74^{\mathrm{a}}$ & $40.35^{\mathrm{a}}$ & 1.03 & 0.2726 \\
\hline HT & $33.87^{\mathrm{c}}$ & $37.18^{\mathrm{a}}$ & $35.19^{\mathrm{b}}$ & 2.05 & 0.0001 \\
\hline BT & $35.08^{\mathrm{b}}$ & $37.87^{\mathrm{a}}$ & $37.87^{\mathrm{a}}$ & 3.28 & 0.0075 \\
\hline BCKT & $33.85^{\mathrm{b}}$ & $37.79^{a}$ & $35.19^{\mathrm{b}}$ & 3.13 & $<0.0001$ \\
\hline WT & 36.86 & 38.12 & 37.62 & 3.08 & 0.1986 \\
\hline LGT & $33.33^{\mathrm{b}}$ & $37.45^{\mathrm{a}}$ & $33.16^{\mathrm{b}}$ & 2.27 & $<0.0001$ \\
\hline $\mathrm{AST}^{3}$ & $33.92^{\mathrm{c}}$ & $37.76^{\mathrm{a}}$ & $35.20^{\mathrm{b}}$ & 2.32 & $<0.0001$ \\
\hline $\mathrm{ABT}^{4}$ & $38.41^{\mathrm{c}}$ & $39.85^{\mathrm{a}}$ & $38.88^{\mathrm{b}}$ & 0.85 & $<0.0001$ \\
\hline \multicolumn{6}{|l|}{42 days } \\
\hline CLT & $40.20^{a}$ & $41.01^{\mathrm{a}}$ & $40.10^{\mathrm{a}}$ & 2.16 & 0.1756 \\
\hline HT & $35.37^{\mathrm{b}}$ & $37.68^{\mathrm{a}}$ & $34.60^{\mathrm{b}}$ & 4.00 & 0.0056 \\
\hline BT & $36.31^{\mathrm{ab}}$ & $37.58^{\mathrm{a}}$ & $35.38^{\mathrm{b}}$ & 3.09 & 0.0141 \\
\hline BCKT & $36.46^{\mathrm{ab}}$ & $37.79^{a}$ & $35.85^{\mathrm{b}}$ & 3.43 & 0.0484 \\
\hline WT & $36.43^{b}$ & $38.46^{\mathrm{a}}$ & $35.60^{\mathrm{b}}$ & 3.50 & 0.0048 \\
\hline LGT & $34.03^{\mathrm{b}}$ & $36.41^{\mathrm{a}}$ & $32.57^{\mathrm{c}}$ & 2.99 & $<0.0001$ \\
\hline $\mathrm{AST}^{3}$ & $36.06^{\mathrm{b}}$ & $37.66^{\mathrm{a}}$ & $35.29^{\mathrm{b}}$ & 2.78 & 0.0032 \\
\hline $\mathrm{ABT}^{4}$ & $38.96^{\mathrm{b}}$ & $40.00^{\mathrm{a}}$ & $38.66^{\mathrm{b}}$ & 2.10 & 0.0306 \\
\hline
\end{tabular}

Averages followed by the same letters in the same line do not differ by the SNK test $(\mathrm{P}>0.05)$.

${ }^{1}$ Variation Coefficient (\%).

${ }^{2}$ Significance of the " $\mathrm{F}$ " test of the variance analysis.

${ }^{3} \mathrm{AST}=(0.12 * \mathrm{WT})+(0.03 * \mathrm{HT})+\left(0.15^{*} \mathrm{LGT}\right)+(0.70 * \mathrm{BCKT}) ;{ }^{4} \mathrm{ABT}=(0.3 * \mathrm{AST})+(0.7 * \mathrm{CLT})(\mathrm{RICHARDS}, 1971)$.

The fact that a difference $(\mathrm{P}>0.05)$ among the CLT of quails (28 and 42 days of age) of the experimental groups (CE, NE, and CECC) was not seen might be an indication that even when kept at high temperature, the NE quails efficiently dissipated the body heat, thus, maintaining their homeothermy. Exposure to high ambient temperatures was the reason for quails of the NE group (28 and 42 days of age) to show higher average temperatures $\left({ }^{\circ} \mathrm{C}\right)$ of the head (CA), breast (BT), back (BCKT), and surface (AST) $(\mathrm{P}<0.05)$ than those of the groups kept at $26{ }^{\circ} \mathrm{C}$.
These results are in agreement with those found by Dahlke et al. (2005), who observed an increase in the surface temperatures of the head, breast, back, and the average surface temperature of 42day old broilers kept at $32{ }^{\circ} \mathrm{C}$, compared with those kept at $22{ }^{\circ} \mathrm{C}$.

Dahlke et al. (2005) argue that the temperature variations on the outer surface of broilers (head, chest, and back) are mechanisms available to the birds to keep their internal temperature constant, suggesting an increase in the heat flow from the body core towards the external surface of the 
body. Based on these factors, the higher surface temperatures of quails kept at $32{ }^{\circ} \mathrm{C}$ than those kept at $26^{\circ} \mathrm{C}$ is justified.

The cloacal temperature of the birds generally varies between $40-42{ }^{\circ} \mathrm{C}$ (BROWN-BRANDT et al., 2003), and when this limit is exceeded, there is an observed difficulty in dissipating body heat by the sensitive means. The results of this study showed that ambient temperatures of $26{ }^{\circ} \mathrm{C}$ or 32 ${ }^{\circ} \mathrm{C}$ allowed the maintenance of a constant bodycore temperature, suggesting that the heat loss mechanisms (sensitive and latent) were sufficient to prevent its variation.

ABT of the NE quails was higher $(\mathrm{P}<0.05)$ when compared with the quails kept at $26^{\circ} \mathrm{C}$, at 28 and 42 days of age. Considering the absence of effect $(\mathrm{P}>$ 0.05) of the ambient temperature on the CLT of quails, most ABT observed in the NE can be attributed to the increased AST, keeping in mind that it is responsible for $30 \%$ of the ABT (RICHARDS, 1971).

The sensitive exchange (conduction, convection, and radiation) of heat is of major importance for thermal balance; however, such a heat-flow mechanism depends directly on a temperature difference (temperature gradient) between the average surface temperature of the bird and the ambient temperature. According to Brown-Brandt et al. (1997), the higher is the temperature differential, more efficient would be the exchange of sensitive heat.

Considering this, the calculated thermal gradients $\left({ }^{\circ} \mathrm{C}\right)$ were $7.82(\mathrm{CE}) ; 5.56(\mathrm{NE})$, and 9.10 (CECC) for 28-day old quails, while for the 42-day old ones, the thermal gradients $\left({ }^{\circ} \mathrm{C}\right)$ were $9.96(\mathrm{CE}) ; 5.46(\mathrm{NE})$, and 9.19 (CECC). These results indicate that quails of the NE group dissipated the metabolic heat by sensitive media at a lower proportion than the birds kept at $26{ }^{\circ} \mathrm{C}$ (28 and 42 days), using evaporative cooling (latent exchange mechanism) as a resource. This mechanism causes greater energy expenditure, resulting in a worse performance (YAHAV et al., 2004), as noted in the quails of the NE group (Table
3) during the accumulated period (14-42 days).

The results of this study showed that, despite the fact that quails raised at $32{ }^{\circ} \mathrm{C}$ showed a lower FI, WG, W42, and CW, compared with those kept at $26{ }^{\circ} \mathrm{C}$, the $\mathrm{FC}, \mathrm{EEWG}$, and carcasses and meat yields were not influenced, showing that this is a technically viable activity, especially in regions where temperatures are high during most of the year, such as the Brazilian Northeast. In this context, there is an alternative for producers in these regions, considering that small areas are needed for the development of this activity, in addition to low need for labor, low initial investment, and quick return of capital, as well as the favorable demand for this meat in the consumer market.

The breeding of meat quails from 14 to 42 days of age is technically feasible in acclimatized $\left(26^{\circ} \mathrm{C}\right)$ and natural $\left(32^{\circ} \mathrm{C}\right)$ environments. Compared with quails from the acclimatized ambient environment, those in the natural environment showed higher performance up to 28 days of age, but the performance decreased from that age onward. The carcass and organ yields and the internal temperature of quails were not influenced by the environment.

\section{Acknowledgments}

We thank Professor Dr. Celso Yoji Kawabata (In Memoriam) for his valuable cooperation in designing, conducting, and writing the essay. We also thank the Foundation for Support to Research and Scientific and Technological Development of the State of Maranhão (FAPEMA) for funding the research. We express our gratitude to the Higher Education Personnel Improvement Coordination (CAPES) for the scholarships granted.

\section{References}

ALVARES, C. A.; STAPE, J. L.; SENTELHAS, P. C.; MORAES, G. J. L. de; SPAROVEK, G. Köppen's climate classification map for Brazil. Meteorologische Zeitschrift, Stuttgart, v. 22, n. 6, p. 711-728, 2013. 
BONNET, S.; GERAERT, P. A.; LESSIRE, M.; CARRE, B.; GUILLAUMIN, S. Effect of high ambient temperature on feed digestibility in broilers. Poultry Science, Savoy, v. 76 , n. 6 , p. $857-863,1997$.

BROWN-BRANDT, T. M.; BECK, M. M.; SCHULTE, D. D.; PARKHURST, A. M.; DeSHAZER, J. A. Physiological responses of tom turkeys to temperature and humidity change with age. Journal of Thermal Biology, Oxford, v. 22, n. 1, p. 43-52, 1997.

BROWN-BRANDT, T. M.; TADAYUKI, Y. J.; HONGWEI, X.; GATES, R. S.; BUCKLIN, R. A. A new telemetry system for measuring core body temperature in livestock and poultry. Applied Engineering in Agriculture, St. Joseph, v. 19, n. 5, p. 583-589, 2003.

BUFFINGTON, D. E.; AROCHO, A. C.; CANTON, G. H.; PITT, D.; THATCHER, W. W.; COLLIE, R. J. Black globe humidity index (BGHI) as a comfort equation for dairy cows. Transaction of the ASAE, St. Joseph, v. 24, n. 3, p. 711-714, 1981.

CHOI, Y. M.; SUH, Y.; SHIN, S.; LEE, K. Skeletal muscle characterization of Japanese quail line selectively bred for lower body weight as an avian model of delayed muscle growth with hypoplasia. PLoS One, San Francisco, v. 9, n. 4, p. 1-14, 2014.

DAHLKE, F.; GONZALES, E.; GADELHA, A. C.; MAIORKA, A.; BORGES, S. A.; ROSA, P. S.; FARIA FILHO, D. E.; FURLAN, R. L. Empenamento, níveis hormonais de triiodotironina e tiroxina e temperatura corporal de frangos de corte de diferentes genótipos criados em diferentes condições de temperatura. Ciência Rural, Santa Maria, v. 35, n. 3, p. 664-670, 2005.

El-DEEP, M. H.; MAHMOUD, H.; DAICHI, I; EID, Y. Z.; HISAYA, Y.; AKIRA, O. Effects of dietary supplementation with Aspergillus awamori on growth performance and antioxidative status of broiler chickens exposed to high ambient temperature. Journal of Poultry Science, Savoy, v. 51, n. 3, p. 281-288, 2014.

GERAERT, P. A.; PADILHA, J. C.; GUILLAUMIN, S. Metabolic and endocrine changes induced by chronic heat exposure in broiler chickens: Growth performance, body composition and energy retention. British Journal of Nutrition, Cambridge, v. 75, n. 2, p. 195-204, 1996.

INSTITUTO NACIONAL DE PESQUISAS ESPACIAIS - INPE. Manual do software SPRING (Sistema de processamento de informações georreferenciadas). Rio de Janeiro: Divisão de Processamento de Imagens, 2010. v.4.3.3.

JORDÃO FILHO, J.; SILVA, J. H. V.; SILVA, C. T.; COSTA, F. G. P.; SOUSA, J. M. B.; GIVISIEZ, P. E. N.
Energy requirement for maintenance and gain for two genotypes of quails housed in different breeding rearing systems. Revista Brasileira de Zootecnia, Viçosa, MG, v. 40, n. 11, p. 2415-2422, 2011.

OBA, A.; LOPES, P. C. F.; BOIAGO, M. M.; SILVA, A. M. S.; MONTASSIER, H. J.; SOUZA, P. A. Características produtivas e imunológicas de frangos de corte submetidos a dietas suplementadas com cromo, criados sob diferentes condições de ambiente. Revista Brasileira de Zootecnia, Viçosa, MG, v. 41, n. 5, p. 11861192, 2012.

OLIVEIRA NETO, A. R.; OLIVEIRA, R. F. M.; DONZELE, J. L.; ROSTAGNO, H. S.; FERREIRA, R. A.; MAXIMIANO, H. C.; GASPARINO, E. Efeito da temperatura ambiente sobre o desempenho e características de carcaça de frangos de corte alimentados com dieta controlada e dois níveis de energia metabolizável. Revista Brasileira de Zootecnia, Viçosa, MG, v. 29, n. 1, p. 183-190, 2000.

OLIVEIRA NETO, A. R.; OLIVEIRA, R. F. M.; DONZELE, J. L.; ROSTAGNO, H. S.; FERREIRA, R. A.; MAXIMIANO, H. C.; GASPARINO, E. Níveis de metionina + cistina para pintos de corte mantidos em ambiente termoneutro. Revista Brasileira de Zootecnia, Viçosa, MG, v. 34, n. 6, p. 1956-1962, 2005.

OLIVEIRA, D. L.; NASCIMENTO, J. W. B.; CAMERINI, N. L.; SILVA, R. C.; FURTADO, D. A.; ARAUJO, T. G. P. Desempenho e qualidade de ovos de galinhas poedeiras criadas em gaiolas enriquecidas e ambiente controlado. Revista Brasileira de Engenharia Agrícola e Ambiental, Campina Grande, v. 18, n. 11, p. 1186-1191, 2014.

OZBEY, O.; OZCELIK, M. The effect of high environmental temperature on growth performance of Japanese quails with different body weights. Journal of Poultry Science, Savoy, v. 3, n. 7, p. 468-470, 2004.

PASTORE, S. M.; OLIVEIRA, W. P.; MUNIZ, J. C. L. Panorama da coturnicultura no Brasil. Revista Eletrônica Nutritime, Viçosa, v. 9, n. 6, p. 2041-2049, 2012.

RICHARDS, S. A. The significance of changes in the temperature of the skin and body core of the chicken in the regulation of heat loss. Journal of Physiology, Cambridge, v. 216, n. 1, p. 1-10, 1971.

ROSA, P. S.; FARIA FILHO, D. E.; DAHLKE, F.; VIEIRA, B. S.; MACARI, M.; FURLAN, R. L. Performance and carcass characteristics of broiler chickens with different growth potential and submitted to heat Stress. Brazilian Journal of Poultry Science, Savoy, v. 9, n. 3, p. 181-186, 2007. 
SAHIN, K.; OZBEY, O.; ONDERCI, M.; CIKIM, G.; AYSONDU, M. H. Chromium supplementation can alleviate negative effects of heat stress on egg production, egg quality and some serum metabolites of laying Japanese quail. The Journal of Nutrition, Bethesda, v. 132, n. 6, p. 1265-1268, 2002.

SAKOMURA, N. K.; ROSTAGNO, H. S. Métodos de pesquisa em nutrição de monogástricos. Jaboticabal: Funep, 2007. 283 p.

SILVA, E. C.; SHIMANO, A. C.; NEDER, L.; ROSSI, A. C.; MARTINEZ, J. A. B. Efeitos da administração sistêmica de corticosteroide sobre propriedades mecânicas musculares. Revista Brasileira de Fisioterapia, São Carlos, v. 9, n. 2, p. 203-209, 2005.

SILVA, J. H. V.; COSTA, F. G. P. Tabela para codornas japonesas e europeias. 2. ed. Jaboticabal: FUNEP, 2009. $110 \mathrm{p}$.

SOUSA, M. S.; TINÔCO, I. F. F., BARRETO, S. L. T.; AMARAL, A. G.; PIRES, L. C.; FERREIRA A. S. Determinação de limites superiores da zona de conforto térmico para codornas de corte aclimatizadas no Brasil de 22 a 35 dias de idade. Revista Brasileira de Saúde e Produção Animal, Salvador, v. 15, n. 2, p. 350-360, 2014.
STATISTICAL ANALYSIS SYSTEM INSTITUTE SAS Institute. Statistical Analysis System for Windows. v. 9.0. Cary: SAS Institute, 2002.

VELDKAMP, T.; TINÔCO, I. F. F.; BARRETO, S. L. T.; AMARAL, A. G.; PIRES, L. C.; FERREIRA, A. S. Growth responses to dietary energy and lysine at high and low ambient temperature in male turkeys. Poultry Science, Savoy, v. 84, n. 2, p. 273-282, 2005.

WIDEMAN, R. F. J.; TACKETT, C. D. Cardiopulmonary function in broilers reared at warm or cool temperatures: Effect of acute inhalation of $100 \%$ oxygen. Poultry Science, Savoy, v. 79, n. 72, p. 257-264, 2000.

YAHAV, S.; STRASCHNOW, A.; LUGER, D.; SHINDER, D.; TANNY, J.; COHEN, S. Ventilation, sensible heat loss, broiler energy, and water balance under harsh environmental conditions. Poultry Science, Savoy, v. 83, n. 2, p. 253-258, 2004.

YUNIANTO, V. D.; HAYASHI, K.; KANEDA, S.; OHTSUKA, A.; TOMITA, Y. D. Effect of environmental temperature on muscle protein turnover and heat production in tube-fed broiler chickens. British Journal of Nutrition, London, v. 77, n. 6, p. 897-909, 1997. 